\title{
Effects of methyl jasmonate and cadmium on growth traits, cadmium transport and accumulation, and allene-oxide cyclase gene expression in wheat seedlings
}

\author{
Ozra Alikhani ${ }^{1}$, Hossein Abbaspour ${ }^{1}$ \\ ${ }^{1}$ Department of Biology, Damghan Branch, Islamic Azad University, Damghan, Iran. E-mail: ozraalikhani@gmail.com, \\ H.Abbaspour@Damghaniau.ac.ir
}

Received: 22/01/2019; Accept: 12/02/2019.

\begin{abstract}
This research investigated the toxicity effects of cadmium chloride $(0,100,200$ and $300 \mu \mathrm{M})$ and its interactive effects with methyl jasmonate (MeJA) $(0,0.01$ and $0.1 \mathrm{mM})$ on growth parameters, cadmium $(\mathrm{Cd})$ accumulation, and Allene-Oxide Cyclase (AOC) gene expression in wheat seedling (Sivand cultivar). According to the results, Cd at concentrations of $200 \mu \mathrm{M}$ and $300 \mu \mathrm{M}$ reduced the growth traits of the wheat. Under exposure to $300 \mu \mathrm{M} \mathrm{Cd}$, root and shoot cadmium content was 30 and 17 times greater than the base level, respectively. Under $100 \mu \mathrm{M} \mathrm{Cd}$ exposures, bioaccumulation factor (BCF) for root and shoot increased by 46 and 25 times respectively. The spraying of MeJA on Cd-stressed plants showed a positive effect on growth parameters, increasing them by 10$40 \%$. The treatment with $0.01 \mathrm{mM}$ jasmonate decreased the accumulation of cadmium in root and shoot by about $30 \%$. The same amount of decrease was observed in BCF after the jasmonate treatment of the specimens exposed to $\mathrm{Cd}$. But application of $0.1 \mathrm{MeJA}$ increased the BCF in most Cd concentrations. Under exposure to $200 \mu \mathrm{M} \mathrm{Cd}$, AOC expression showed an approximately three fold increase. The use of $0.1 \mathrm{mM} \mathrm{MeJA}$ also resulted in a fourfold increase in AOC gene expression. It can conclude that MeJA showed a substantial impact on Cd accumulation and AOC gene expression in wheat seedling.
\end{abstract}

Keywords: Triticum aestivum L., growth traits, toxicity effect.

\section{Efeitos do metil jasmonato e cádmio nas características de crescimento, acúmulo e transporte de cádmio e expressão gênica da aleno óxido ciclase em mudas de trigo}

\section{RESUMO}

Este estudo avaliou os efeitos da toxicidade do cloreto de cádmio $(0,100,200$ e $300 \mu \mathrm{M})$ e seus efeitos da interação com o metil jasmonato (MeJA) (0, 0,01 e 0,1 mM) sobre os parâmetros de crescimento, acúmulo de cádmio $(\mathrm{Cd})$ e experessão gênica da Aleno Óxido Ciclase (AOC) em mudas de trigo (cultivar Sivand). De acordo com os resultados, o Cd nas concentrações de $200 \mu \mathrm{M}$ e $300 \mu \mathrm{M}$ reduziu as características de crescimento do trigo. Sob exposição a $300 \mu \mathrm{M} \mathrm{Cd}$, o conteúdo de cádmio nas raízes e na parte aérea foi 30 e 17 vezes maior do que o nível básico, respectivamente. Sob exposição a $100 \mu \mathrm{M} \mathrm{Cd}$, o fator de bioacumulação (FBC) para raiz e parte aérea aumentou em 46 e 25 vezes, respectivamente. A pulverização de MeJA em plantas sob estresse por Cd mostrou um efeito positivo nos parâmetros de crescimento, aumentando de 10 para $40 \%$. O tratamento com jasmonato $0,01 \mathrm{mM}$ diminuiu o acúmulo de cádmio na raiz e na parte aérea em cerca de 30\%. A mesma quantidade de decréscimo foi observada no FBC após o tratamento com jasmonato nas plantas expostas ao Cd. Porém, a aplicação de 0,1 MeJA aumentou o FBC na maioria das concentrações de Cd. Sob exposição a $200 \mu \mathrm{M} \mathrm{Cd}$, a expressão de AOC mostrou um aumento de aproximadamente três vezes. O uso de MeJA 0,1 mM também resultou em um aumento de quatro vezes na expressão do gene AOC. Pode-se concluir que MeJA apresentou um impacto substancial no acúmulo de Cd e na expressão do gene AOC em mudas de trigo.

Palavras-chave: Triticum aestivum L., traços de crescimento, efeito de toxicidade. 


\section{Introduction}

With the progress and growth of industrial activities, the environmental damage caused by the accumulation of metals and semimetals has become a threat to the life of plants and animals. Metals with a density of more than $5{\mathrm{~g} . \mathrm{cm}^{-}}^{3}$ are known as heavy metals. Of the 90 naturally abundant elements, 53 are heavy metals, and depending on their solubility in physiological conditions, 17 of these elements may contaminate the living cells (Hasan et al., 2009). Some of these metals like zinc, mercury, copper, arsenic, lead, and $\mathrm{Cd}$, are persistent elements and can undergo significant bioaccumulation. Among the heavy metals, $\mathrm{Cd}$ is known for its widespread industrial use as well as the dangers of its high accumulation to human health. Plants account for about $70 \%$ of $\mathrm{Cd}$ intake in humans (Ouzounidou et al., 1997). Cd concentration ranges from $0.04 \mathrm{mM}$ to $0.32 \mathrm{mM}$ in non-contaminated soils, and from 0.32 to $1 \mathrm{mM}$ in contaminated soil (Gubrelay et al., 2013). Cd in the soil-root system has a relatively high ability to transport and inhibits the growth of roots and aerial organs. It also has an antagonistic effect on the absorption of some mineral elements that leading to a lack of essential elements inside the plant (Nazar et al., 2012). Research conducted on soybean (Perez Chaca et al., 2014), wheat (Alayat et al., 2014), lettuce (Dias et al., 2013), sorghum (Da-lin et al., 2011), pea (Bavi et al., 2011) and many other plants has shown that $\mathrm{Cd}$ toxicity is associated with reduced plant growth, reduced water content, oxidative stress, and reduced mineral absorption and had damaging effects on the photosynthesis mechanism and carbohydrate assimilation.

When plants are subjected to Cd stress, a variety of reactive oxygen species (ROS) are generated. These ROS are toxic to living organisms unless removed rapidly, destroyed or inactivated by various cellular components. In the absence of effective mechanisms that remove or scavenge free radicals, they can seriously damage plant by lipid per-oxidation, protein degradation, breaking of DNA and cell death (Thian and $\mathrm{Li}$, 2006).

It has been proven that when subjected to heavy metal stress, plants adjust their internal hormones to adapt to situations. Abiotic stress stimulates the internal jasmonate in plants (Chen et al., 2014). Many studies have shown that treatment with MeJA eliminates oxidative stress in plants. MeJA can affect tissue resistance to biotic and abiotic stresses by enhancing antioxidant systems and their ability to purify free radicals. Under Cd stress, jasmonates activate the genes involved in the signal transduction pathway for $\mathrm{Cd}$ and regulate the glutathione increase and phytochelatin accumulation (Dar et al., 2015). MeJA treatment of rice seedlings under $\mathrm{Cd}$ stress has been found to increases the activity of lipoxygenase, and reduced $\mathrm{Cd}$ accumulation in roots and leaves (Singh and Shah, 2014).

When MeJA was used at the concentration of 0.01 $\mathrm{mM}$ in Soyabean, it reduces the Cd damage by $30 \%$ and $20 \%$ caused to shoot dry weight and to the total chlorophyll content. Similar results have been obtained in Arabidopsis thalina when MeJA was used at the concentration of 0.01 and $0.1 \mathrm{mM}$ to deal with the $\mathrm{Cd}$ stress (Maksymiek and Krupa, 2006). In Capsicum frutescens seedlings $0.1 \mu \mathrm{mol} \mathrm{L^{-1 }}$ MeJA mitigates the Cd damage by improving the chlorophyll content and activities of antioxidant enzymes (Yan et al., 2013). MeJA (0.1 to $1 \mu \mathrm{mol}$ L-1-) protects Kandelia obovata seedlings against $\mathrm{Cd}$ stress by discouraging $\mathrm{Cd}$ uptake/translocation to leaves and increasing the concentration of ascorbic acid and the activities of antioxidant enzymes (Chen et al., 2014). It has also been reported that MeJA provide tolerance to Arabidopsis thaliana plants against $\mathrm{Cd}$ stress by the accumulation of phytochelatins (PCs) (Maksymiec et al., 2005).

Both $\mathrm{Cd}$ and MeJA stimulate increase in ROS accumulation in their action and even involvement of MeJA in Cd-induced ROS increase (Maksymiec and Krupa, 2006).

An essential step in the jasmonic acid (JA) biosynthesis is catalyzed by the allene-oxide cyclase (AOC). AOC (EC: 3.5.99.6) is responsible for cyclization of unstable allene-oxide into the stable 12oxo-(10,15Z)-phytodienoic acid (OPDA), which is the precursor to JA synthesis. This is an essential step in jasmonate biosynthesis. The expression of AOC genes increased temporarily after wounding or JA treatment (Stenzel et al., 2003). It reported that AOC gene expression is also associated with improved copper tolerance in cotton. In Arabidopsis plants, GhAOC1 overexpression has been found to be associated with higher survival rate, higher fresh and dry weight of the shoot, improved photosynthetic efficiency and reduced cell membrane damage and lipid peroxidation under copper-induced stress (Wang et al., 2015). In two species of transgenic wheat and Arabidopsis, the TaAOC1 gene has been found to be associated with increased salinity tolerance and jasmonate accumulation (Zhao et al., 2014).

Characterization of these genes from different research has provided valuable information about their physiological and biochemical roles in adaptation to a variety of stresses. GmAOC5 in transgenic tobaccos showed enhanced tolerance to oxidative stresses, while in GmAOC1-expressing transgenic lines observed enhanced salinity stress tolerance (Wu et al., 2011). As one of the most important crops, wheat suffers from various environmental stresses, such as drought, salinization, and heavy metals. Understanding the 
molecular basis of stress responses is accordingly a key target of wheat genetic improvement programs. The aim of present study was to examine the role of MeJA on growth parameters, AOC gene expression, and $\mathrm{Cd}$ accumulation in shoots and roots of the wheat seedling under $\mathrm{Cd}$ accumulation.

\section{Material and Methods}

\subsection{Plant cultivation and treatment}

Wheat seeds of Sivand cultivar were obtained from Neyshabur Agricultural Research Center. The seeds were sterilized with $5 \%$ sodium hypochlorite solution for 10 minutes and then washed with distilled water three times and planted, filled with sterile soil and perlit. So that ultimately each pot contained 20 seeds. Initial irrigation was performed with distilled water. After germination, irrigation was continued with Hoagland's nutrient solution and the specimens were transferred to a growth chamber with $23 / 18^{\circ} \mathrm{C}$ temperature and a $16 \mathrm{~h}$ light $/ 8 \mathrm{~h}$ dark photoperiod, with a relative humidity of $70 \%$. Once the plant reached 2-3 leaf stage, $\mathrm{Cd}$ treatment was performed by adding $150 \mathrm{~mL} \mathrm{CdCl}_{2}$ solution to Hoagland at concentrations of $(0,100,200$, $300 \mu \mathrm{M})$. At the same time, leaves were sprayed with $100 \mathrm{~mL}$ MeJA solution at concentrations of $(0,0.01$, $0.1 \mathrm{mM})$. In control plants, leaves were sprayed with water. Hormonal and $\mathrm{Cd}$ treatments were applied every other day for two weeks. Then, samples were harvested and their morphological traits were measured. For further measurements, samples were stored in $-70^{\circ} \mathrm{C}$.

\subsection{Trait measurements}

Growth traits

- To measure morphological parameters (length, fresh weight, and dry weight of root and stem), three samples were taken from each replicate. Root length, stem length and fresh weight of the sample were measured immediately after harvest. Dry weight was measured after drying roots and stems in an oven at $60{ }^{\circ} \mathrm{C}$ for 48 hours. Both weights were measured using a scale with a precision of $0.001 \mathrm{~g}$.

\subsection{Cd uptake, transfer, and bioaccumulation in root and shoot}

- To determine the $\mathrm{Cd}$ content of the root and aerial part, samples were placed in oven at $70{ }^{\circ} \mathrm{C}$ for 24 hours. Then a $0.5 \mathrm{~g}$ of the leaf tissue and a $0.2 \mathrm{~g}$ of the root sample were extracted and placed in $10 \mathrm{ml}$ of nitric acid. The samples were kept in acid for a week to reach full tissue decomposition and then filtered by filter paper. After bringing the solution to a volume of $50 \mathrm{ml}$, it was scanned by an Atomic Absorption Spectrometer (VARIAN AA240, AGILENT, USA) to determine the
Cd content based on sample absorption. Standard concentrations were used to draw a standard curve and estimate unknown concentrations.

Bioaccumulation factor (BCF) and transfer factor (TF), which represent the ability of the plant to tolerate and accumulate heavy metals in its organs, were determined by calculating the ratio of $\mathrm{Cd}$ concentration in the plant to metal content of the soil and the ratio of metal concentration in the aerial organ to metal content of the underground organ.

\subsection{Molecular assays}

RNA exctraction and first strand cDNA synthesis

- The design of primers of the Actin (internal control) gene and AOC gene with the access code KF039887.1 in the wheat plant was carried out in accordance with the primer design standards and with the assistance of Oligo software (ver 7.59) (Table 1).

From each sample, $100 \mathrm{mg}$ of leaf tissue was ground in a porcelain mortar with liquid nitrogen. RNA extraction was performed using the column-based method and commercial extraction kit (Denazist). For quantitative and qualitative evaluation of extraction, samples of extracted RNA were subjected to gel electrophoresis. Absorbance of RNA concentration was determined by at $260 \mathrm{~nm}$ with a NanoDrop spectrophotometer (WPA-biowave II) and it's intensify was visualized on $1 \%$ agarose gel. Approximately, $2 \mu \mathrm{g}$ of total RNAs was treated with RNase-free DNase (Fermentas) and first strand of cDNA was synthesized by using of M-MULV reverse transcriptase kit (Thermo Scientific) and primers of oligo (dT) according to manufacturer's instructions. The rest of the procedure was carried out as instructed in the kit manual.

\subsection{Real-time PCR analysis}

- Then, the AOC gene expression was examined using the Real-time PCR with target gene primers, actin primers, and cDNA samples and amplification of their fragments. The actin gene was used as the control. At this stage, gene fragment amplification reaction was carried out using the Maxima SYBR Green kit (Thermo Scientific) and the StepOne Applied Biosystems (ABI) instrument.

For Real-time PCR following program was used: 15 min in $95{ }^{\circ} \mathrm{C}$, denaturation process for $15 \mathrm{~S}$, annealing and extension for $30 \mathrm{~S}$ at $57{ }^{\circ} \mathrm{C}$ for 40 cycles. For checking of the amplified product melt curve analysis was performed. Actin as the housekeeping gene for calculating of relative transcript levels was chosen. Transcription was determined by amplifying three genes in duplicates for each treatment. For determination of relative gene induction levels, the $\Delta \mathrm{CT}$ method was used (Livak and Schmittgen, 2001). 
Table 1. DNA sequences for primers used in Real-time PCR to measure AOC in comparison to Actin housekeeping gene.

\begin{tabular}{lccc}
\hline Gene & Accession number & 5'-Forward primer-3' & 5'-Reverse primer-3' \\
\hline $\boldsymbol{A} \boldsymbol{O C}$ & AN_0157770.1 & CGTCTTCGAGGGCGTCTACG & GCAGGTCGGGGATGCCCTTG \\
$\boldsymbol{a c t i n}$ & XM_004135239.2 & ACCTTCAGTTGCCCAGCAAT & CAGAGTCGAGCACAATACCAGTTG \\
\hline
\end{tabular}

\subsection{Data analysis}

- Statistical analysis was performed using the software SAS (v.9.4) and Statistix (v.8). Data are showed as the average of independent experiments and analyzed by means of two-way ANOVA. Means were compared with the Tukey test at a significance level of 0.05 .

Analysis of variance was carried out at 95\% confidence interval and means were compared by LSDtest. The standard charts and curves were drawn using Excel software.

\section{Results and Discussion}

\subsection{Plant growth parameters}

- Cd treatments at $200 \mu \mathrm{M}$ and $300 \mu \mathrm{M}$ reduced most growth parameters. MeJA treatment, especially at a concentration of $0.01 \mathrm{mM}$, had a positive impact on growth traits. Cd treatment had no significant impact on shoot length. However, as the $\mathrm{Cd}$ concentration increased, the root length slightly decreased. Under Cd stress, MeJA treatment increased the root length by about 10\% (compared to control) (Figure 1). The fresh weights of both root and shoot were also reduced by $\mathrm{Cd}$. Under exposure to $200 \mu \mathrm{M} \mathrm{Cd}$, treatment with $0.01 \mathrm{mM}$ MeJA increased the fresh weight of the root by about $28 \%$. Under exposure to $300 \mu \mathrm{M} \mathrm{Cd}$, the same concentration of MeJA increased the fresh weight of the shoot by about $20 \%$ (Figure 2). The greatest effect of MeJA treatment on the dry weight of root and shoot was observed in the samples exposed to $\mathrm{Cd}$ at a concentration of $300 \mu \mathrm{M}$. In these cases, $0.01 \mathrm{mM}$ MeJA increased the dry weight of root and stem by $32 \%$ and $42 \%$, respectively (Figure 3 ).

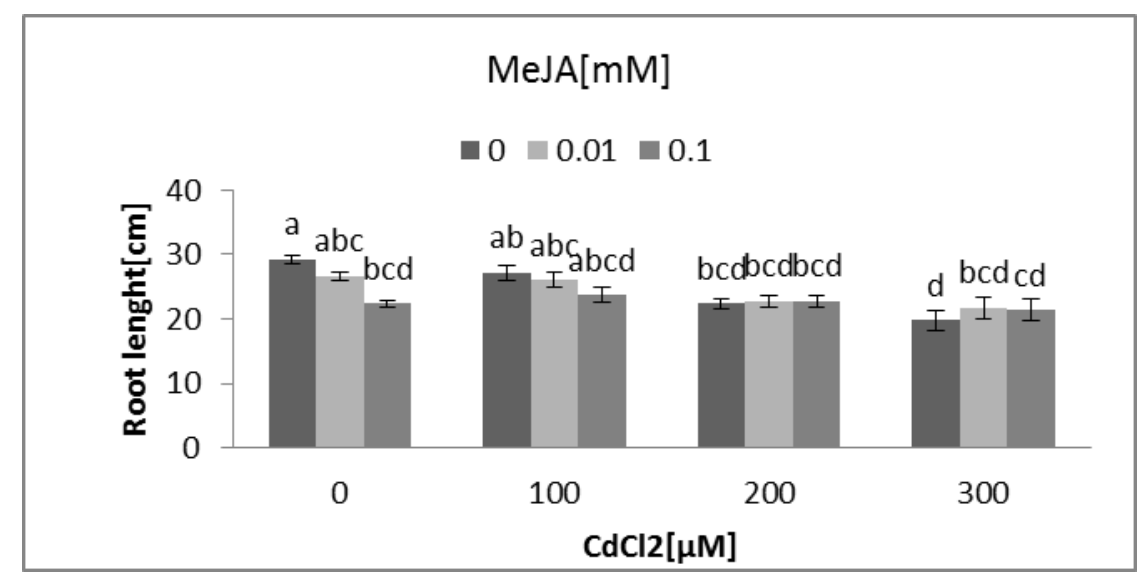

Figure 1. The interactive effects of MeJA application and Cd stress on root length of Triticum aestivum seedlings. P values for Cd stress, MeJA and the interaction between them were $<0.01,<0.05$ and $<0.05$. Each bar is mean of three replication. Means comparison was performed according to LSD test $(P \leq 0.05)$.
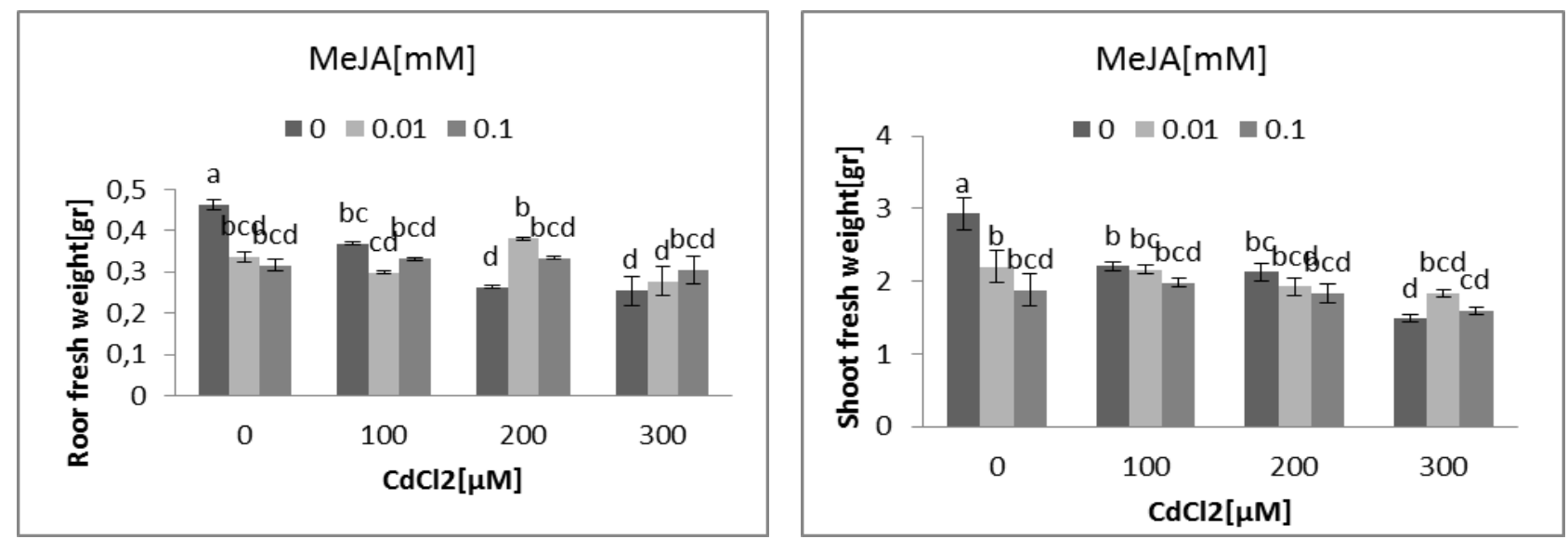

Figure 2. The interactive effects of MeJA application and Cd stress on root fresh weight and shoot fresh weight of Triticum aestivum seedlings. P values for Cd stress, MeJA and the interaction between them were $<0.01,>0.05$ and $<0.05$. Each bar is mean of three replication. Means comparisons were performed according to LSD test $(P \leq 0.05)$. 

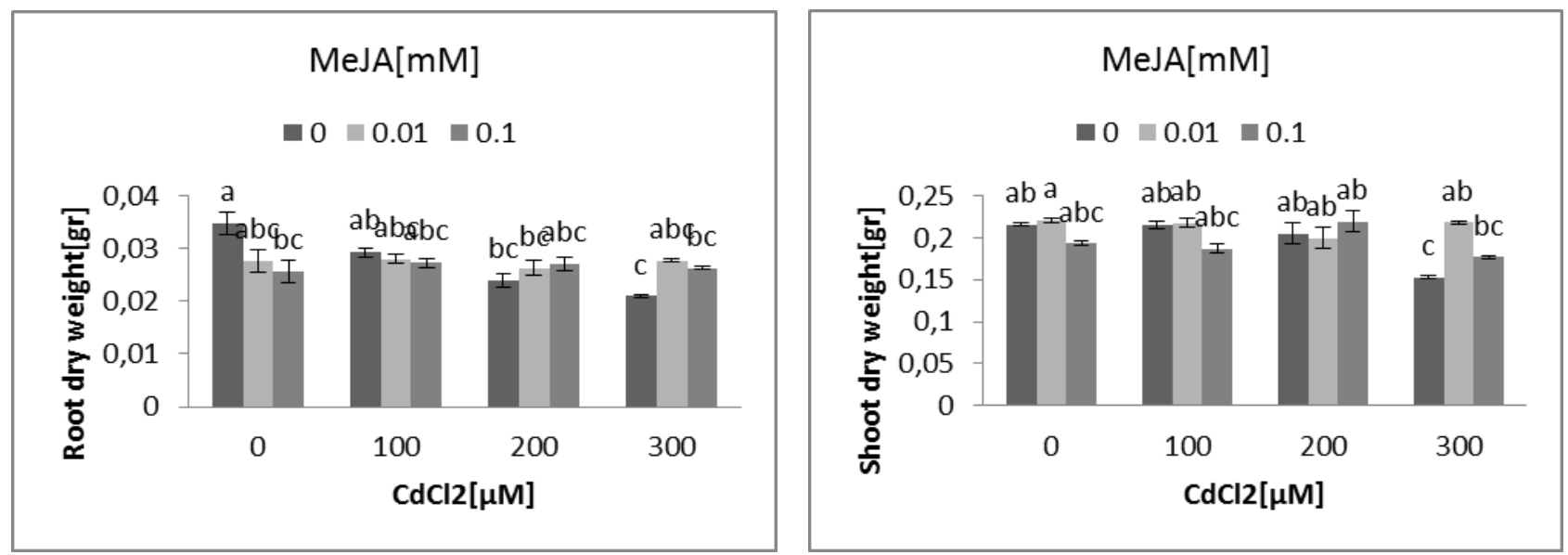

Figure 3. The interactive effects of MeJA application and Cd stress on root dry weight and shoot dry weight of Triticum aestivum seedlings. $\mathrm{P}$ values for Cd stress, MeJA and the interaction between them were $<0.01,>0.05$ and $<0.01$. Each bar is mean of three replication. Means comparisons were performed according to LSD test $(P \leq 0.05)$.

\subsection{Cd accumulation}

- As the Cd concentration increased, so did its accumulation in roots and stems. The Cd content of the root was found to be about 2.5 times the amount measured in the shoot. Examination of the results of hormonal treatment showed that MeJA with a concentration of $0.01 \mathrm{mM}$ reduced the $\mathrm{Cd}$ accumulation in root and shoot by $30 \%$, but higher concentrations of this hormone $(0.1 \mathrm{mM})$ increased the Cd content of both shoot and root by $11-12 \%$ (Figure 4 ).

The highest $\mathrm{Cd}$ bioaccumulation in root and shoot was observed under exposure to the $\mathrm{Cd}$ at a concentration of $20 \mathrm{mg} \mathrm{l}^{-1}(100 \mu \mathrm{M})$ and was about 46 and 25 times greater than the normal level respectively. However, with further increase in $\mathrm{Cd}$ concentration, its bioaccumulation in both organs decreased so that under the $\mathrm{Cd}$ concentration of $60 \mathrm{mg} \mathrm{l}^{-1}(300 \mu \mathrm{M})$, it reached to approximately 38 and 18 times greater than the normal level respectively (Figure 4).

The effect of MeJA alone on Cd bioaccumulation was not significant; but analysis of its interaction with
Cd showed that in $20 \mathrm{mg} \mathrm{l}^{-1} \mathrm{Cd}$ treatment $(100 \mu \mathrm{M})$, $0.01 \mathrm{mM}$ MeJA decreased the BCF in root by more than $30 \%$, whereas $0.1 \mathrm{mM}$ MeJA increased BCF by about $13 \%$.

On the contrary, at $20 \mathrm{mg} 1 \mathrm{Cd}$ concentrations in shoot, application of $0.01 \mathrm{mM}$ MeJA increased BCF in shoot by $41 \%$, but reduced it at higher concentrations of $\mathrm{Cd}$, whereas application of $0.1 \mathrm{mM} \mathrm{MeJA}$ at higher concentration of $\mathrm{Cd}$ in shoot increased this parameter by 10\%-30\% (Figure 5).

- At all concentrations, transfer factor (TF) was less than 1 which indicates that most $\mathrm{Cd}$ accumulation remains in the root.

- It was verified that the transfer factor (TF) was affected by various concentrations of $\mathrm{Cd}$ and its interactions by MeJA. With increasing $\mathrm{Cd}$ concentration, the transfer rate from root to stem has decreased than the control. This decrease was $25 \%$ at a concentration of $20 \mathrm{mg} \mathrm{l}^{-1}$ and at higher levels of $\mathrm{Cd}(40$ and $60 \mathrm{mg} \mathrm{l}^{-1}$ ) were $37 \%$ and $42 \%$ respectively (Figure $6)$.
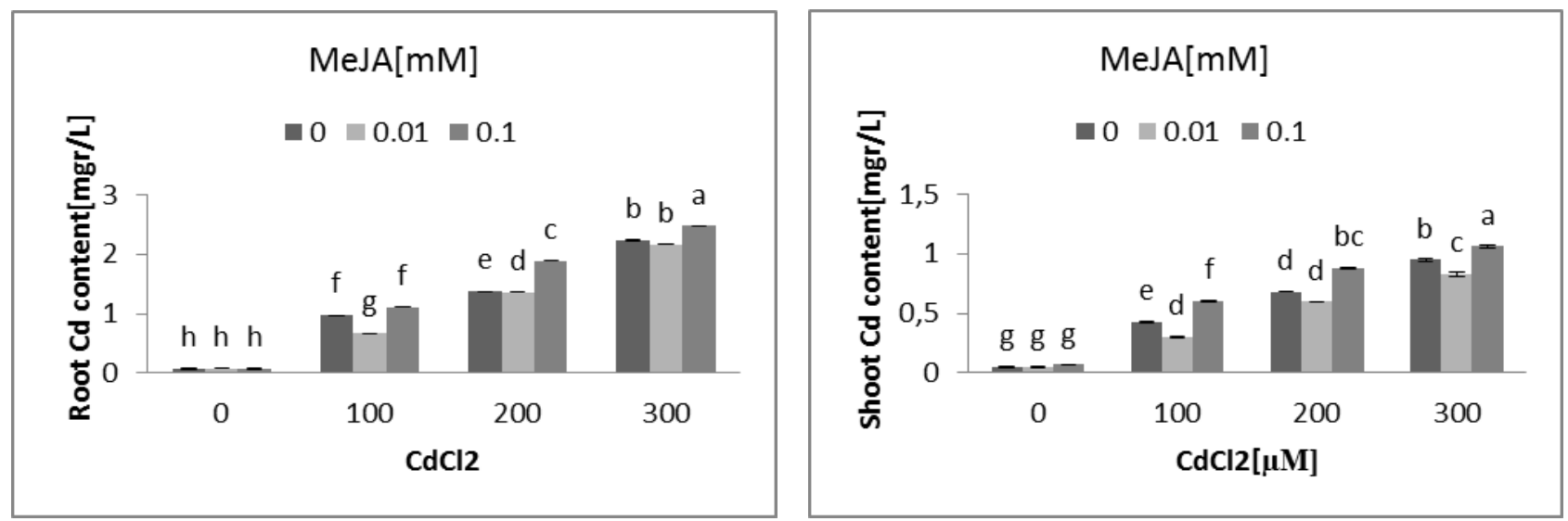

Figure 4. The interactive effects of MeJA application and $\mathrm{Cd}$ stress on root $\mathrm{Cd}$ content and shoot Cd content of Triticum aestivum seedlings. $\mathrm{P}$ values for $\mathrm{Cd}$ stress, MeJA and the interaction between them for root $\mathrm{Cd}$ content were $<0.01$. This $\mathrm{P}$ value for shoot $\mathrm{Cd}$ content were $0.01,0.05$ and 0.05 . Each bar is mean of three replication. Means comparisons were performed according to LSD test $(P \leq 0.05)$. 

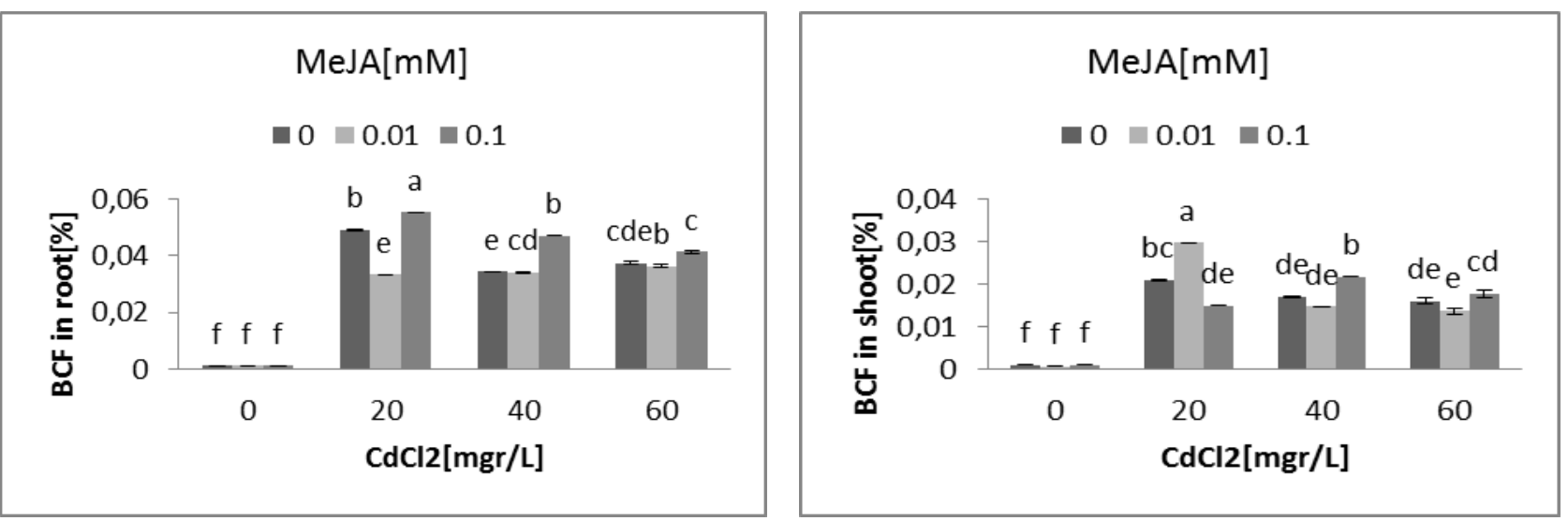

Figure 5. The interactive effects of MeJA application and Cd stress on root BCF and shoot BCF and transfer fector (TF) of Triticum aestivum seedlings. $\mathrm{P}$ values for $\mathrm{Cd}$ stress, MeJA and the interaction between them for Root $\mathrm{BCF}$ were $<0.01$, and for shoot $\mathrm{BCF}$ were $0.01,0.05$ and 0.01 . Each bar is mean of three replication. Means comparisons were performed according to LSD test $(P \leq$ $0.05)$.

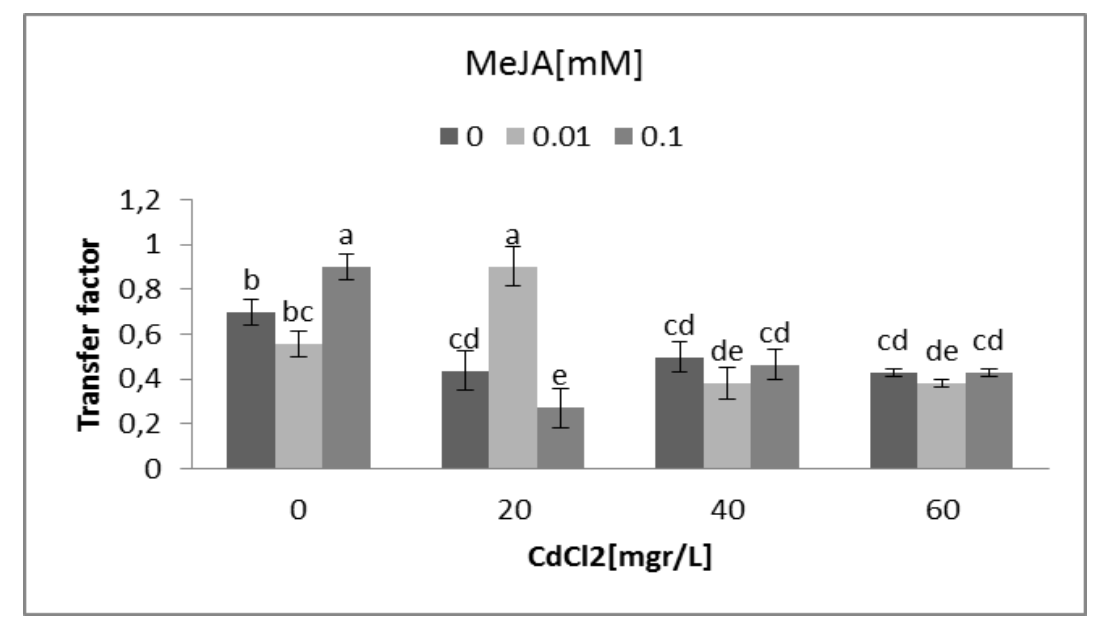

Figure 6. The interactive effects of MeJA application and Cd stress on transfer fector (TF) of Triticum aestivum seedlings. $\mathrm{P}$ values for Cd stress, MeJA and the interaction between were $0.01,0.05$ and 0.01. Each bar is mean of three replication. Means comparisons were performed according to LSD test $(P \leq 0.05)$.

\subsection{Molecular assay}

- AOC gene expression increased with the increase in $\mathrm{Cd}$ concentration. Ultimately, at $300 \mu \mathrm{M} \mathrm{Cd}$ concentration, AOC gene expression became 2.6 fold greater than its base value at $0 \mathrm{Cd}$ concentrations (control plant). Analysis of interactions showed that $\mathrm{Cd}$ at a concentration of $200 \mu \mathrm{M}$ and MeJA at a concentration of $0.1 \mathrm{mM}$ both had a significant impact on the expression of this gene and increased it by 4.6 fold (Figure 7).

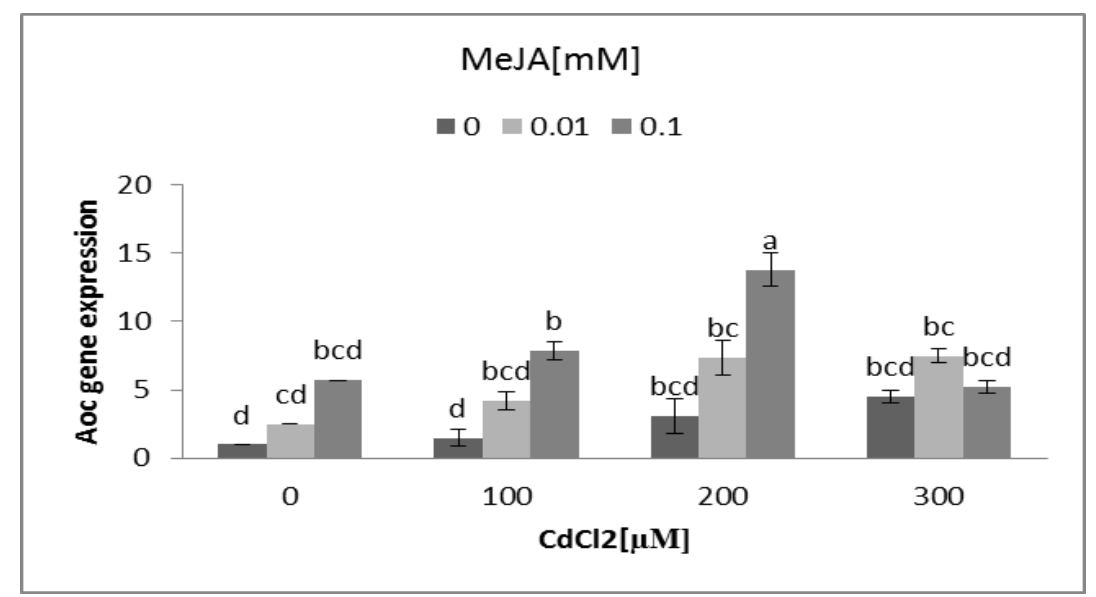

Figure 7. The interactive effects of MeJA application and Cd stress on AOC gene expression of Triticum aestivum seedlings. $\mathrm{P}$ values for Cd stress, MeJA and the interaction between them were 0.01. Each bar is mean of three replication. Means comparisons were performed according to LSD test $(P \leq 0.05)$. 
AM is a strategy for detecting QTLs in which biparental crosses and screening generations of progeny are not necessary. Evaluation of associations between genotypes and phenotypes using AM based on statistical models approves the technique to any set of germplasm to detect QTLs for various traits (Roy et al., 2010). The charts showed the reduced growth parameters of wheat seedling under the stress induced by $\mathrm{Cd}$ at concentrations of $100 \mu \mathrm{M}, 200 \mu \mathrm{M}$, and especially 300 $\mu \mathrm{M}$. In our study, Cd stress reduced the root length but did not have a significant effect on shoot length. These results are expected, because $\mathrm{Cd}$ first gathers in the root, and the root remains the primary point of $\mathrm{Cd}$ accumulation (De Maria et al., 2013). On the other hand, $\mathrm{Cd}$ reduces the mitosis division in the root apical meristem. In addition, the negative effect of $\mathrm{Cd}$ on root growth can be partly due to an increase in the amount of ABA in root. Moreover, inhibition of root growth under $\mathrm{Cd}$ stress reduces the water and minerals absorption, thereby inhibiting the plant's metabolism (Perez Chaca et al., 2014). Chlorophyll degradation, enzyme deactivation, water and mineral deficiency, and decomposition of the membrane lipid structure are among the important factors that undermine plant metabolism and inhibit plant growth under $\mathrm{Cd}$-induced stress.

Heavy metals can disrupt the photosynthetic electron transport chain, leading to superoxide and singlet oxygen formation, and thereby indirectly contribute to the ROS generation and creation of oxidative stress (Benavides et al., 2005). ROS accelerate lipid peroxidation and thus affect membrane fluidity and permeability by changing the composition of membrane lipids (Azevedo et al., 2012). Cd can also replace magnesium ions in chlorophyll molecules, thereby causing chlorophyll instability and degradation (Kupper and Andresen, 2016).

In the analysis of exclusive effects of MeJA, it was found that although all Cd-stressed samples had lower growth parameters than control samples, MeJA treatment still had significant positive impact on growth traits of the plants under Cd stress. The negative impact of MeJA on growth under normal conditions (without Cd-induced stress) can be attributed to the jasmonate's stimulation of auxin production in the root.

Jasmonate isoleucine sprays anthranilate synthase-1 (ASA1) in the auxin biosynthesis pathway, thereby inhibiting the root growth. MeJA also inhibits the expression of genes encoding the PLETHORA transcription factors (PLT1), which induce meristemic activity in the root (Wasternack and Hause, 2013). In a research on rice seedling, it was observed that MeJA alone had a slightly negative effect on growth traits, but in the presence of Cd stress, the use of MeJA led to significant changes in the activity of antioxidant enzymes and glutathione reductase levels (Singh and Shah, 2014).

In a study conducted by Yoon et al. (2009), the use of $20 \mu \mathrm{M}$ and $30 \mu \mathrm{M}$ MeJA reduced the damaging effects of salinity on growth traits and increased the levels of some plant regulators. In salt stressed soybean plants, spraying of MeJA decreased the effects of stress on growth traits. These effects of MeJA on growth may be due to the role of this hormone in membrane stabilization under stress conditions (Sheteawi, 2007).

In the present research, $\mathrm{Cd}$ treatment led to the accumulation of this heavy metal in both stem and root, but especially in the latter.

Researches has shown that roots are the primary point of heavy metals accumulation (De Maria et al. 2013) and the next most critical organs in this regard are the shoot, leaves, fruits, and seeds in that order (Benavides et al., 2005). Root secretions or the presence of nitrogen can acidify the soil environment, thereby increasing the dissolution of metal ions in the soil. The solubility of heavy metals is also affected by soil $\mathrm{pH}$. The secretions of microbes around the root also affect the heavy metal absorption or chelation (Wang et al., 2017).

In this research, bioaccumulation factor $(\mathrm{BCF})$ in root and stem (i.e., the ratio of $\mathrm{Cd}$ concentration in each organ to $\mathrm{Cd}$ concentration in the soil), decreased with the increase of applied $\mathrm{Cd}$ concentration. The results show that BCF is less than 1 , indicating that $\mathrm{Cd}$ accumulation in the plant is less than that in the soil. In this case, it can be said that the plant can absorb the heavy metal, but cannot accumulate it (Liu et al., 2009). According to the results, the transfer factor (TF) is also less than 1 , indicating that $\mathrm{Cd}$ content is higher in the root than in the stem. Past researches on the heavy metal accumulation in wheat has shown that $\mathrm{Cd}$ uptake was more than other heavy metals, and $\mathrm{Cd}$ accumulation reduced in the following order: root> shoot> seed (Wang et al., 2010; Liu et al., 2009).

In plants with a transfer factor higher than 1, plants can be used to refine heavy metal from the soil. This case was observed in Aeluropus littoralis. This plant has bio-accumulation and transfer factor of more than 1 in the presence of $\mathrm{Cd}$, while for lead these parameters were less than 1 (Rezvani and Zaefarian, 2011).

Our research showed that $\mathrm{BCF}$ and $\mathrm{TF}$ are highest under exposure to $\mathrm{Cd}$ with a concentration of $100 \mu \mathrm{M}$ (20 mg/L) and higher Cd concentrations lead to lower $\mathrm{BCF}$ and TF (i.e. decreasing $\mathrm{Cd}$ concentration in the tissues compared to the soil). This could be due to the activation of intracellular $\mathrm{Cd}$ stress inhibiting mechanisms at $\mathrm{Cd}$ concentrations of more than $100 \mu \mathrm{M}$. The tolerance mechanism against $\mathrm{Cd}$ accumulation, is storing $\mathrm{Cd}$ by binding it to amino acids, proteins and peptides (e.g. binding to phytochelatins and 
metallothioneins) and also by increasing the level of salicylic acid, jasmonic acid and ethylene in the cell (Azevedo et al., 2012).

According to our results, MeJA had a dual effect on $\mathrm{Cd}$ accumulation in root and stem. At a concentration of $0.01 \mathrm{mM}$, MeJA had a decreasing effect on the accumulation of $200 \mu \mathrm{M}$ and $300 \mu \mathrm{M} \mathrm{Cd}$, but at higher MeJA concentration $(0.1 \mathrm{mM})$ this hormone increased the accumulation of $\mathrm{Cd}$. While low concentrations of MeJA can enhance the plant tolerance to stress, high concentrations of MeJA inhibit growth and photosynthesis and accelerate aging (Yan et al., 2015).

On the other hands, MeJA activate the genes involved in the $\mathrm{Cd}$ signaling pathway and upregulate the glutathione and accumulate phytochelatin, thereby decreasing the intracellular $\mathrm{Cd}$ concentration and its toxic effects (Dar et al., 2015).

In a research on the effect of this hormone on the regulation of $\mathrm{Cd}$ accumulation and antioxidant capacity of Solanum nigrum L., which has a significantly high $\mathrm{Cd}$ accumulation capability, the use of $0.01 \mu \mathrm{M}$ MeJA alongside $\mathrm{Cd}$, as opposed to the use of $\mathrm{Cd}$ alone, greatly increased the $\mathrm{Cd}$ transfer and accumulation in both root and stem (Yan et al., 2015). The use of MeJA in Kandelia obovata seedling inhibited the $\mathrm{Cd}$ absorption in the stem, and thereby reduced the damage to the photosynthetic system. This decrease in absorption may be due to the effect of exogenous MeJA on the closure of stomata and the reduction of transpiration (Chen et al., 2014).

Past research on signal transduction suggests the involvement of MeJA in the process of heavy metal detoxification. This suggests that heavy metal stress may induce jasmonate synthesis, and therefore, this hormone may act as a stimulant for toxicity signs through changes in gene expressions (Mishra and Dubey, 2006). Because of AOC is key enzyme in MeJA biosynthesis, after treatment of plant with MeJA, led to induction of their biosynthesis pathway. In the present study, MeJA increased AOC gene expression, and its peak effectiveness in this respect was observed under exposure to $200 \mu \mathrm{M} \mathrm{Cd}$.

It was reported that the expression of the JA biosynthesis pathway genes could be induced by different treatments such as JA. Moreover, MeJA can induce expression of the genes encoding enzymes specific for JA biosynthesis in various plant species (Browse, 2009). Some research was reported that MeJA can induce the expression of AOC, suggesting that the exogenous MeJA may affect the JA biosynthesis in tea plant. Result of our study is agreement with finding of Singh and Shah, who have indicated that the exogenousMeJA alleviated cadmium-induced oxidative injury through JA pathways (Singh and Shah, 2014). It was reported that dynamic expression patterns of AOC were affected by $\mathrm{MeJA}$ and $\mathrm{CuCl}_{2}$, suggesting that AOCs are involved in the crosstalk of the environmental stress response in cotton. The similar results of our study were observed under $\mathrm{CuCl}_{2}$ stress plant. It reported that AOCs were upregulated by MeJA and suggests that the induction of $\mathrm{AOC}$ gene by $\mathrm{CuCl}_{2}$-induced stress is associated with the MeJA-mediated signaling pathway (Creelman and Mullet, 1997).

Researches on Arabidopsis suggested that the higher tolerance to $\mathrm{Cd}$ stresses which observed in AOCoverexpressing was the result of the increased expression levels of these genes.

In Arabidopsis plants, four genes encode four functional AOC polypeptides, AOC1, AOC2, AOC3, and AOC4. A research on mutants has shown that all types of AOCs can interact with each other. This suggests the existence of a mechanism for temporal and spatial regulation of JA formation by differential expression of AOC polypeptides (Stenzel et al., 2012). Schaller et al. (2008) reported that all four types of isoenzymes can be involved in MeJA biosynthesis and are positioned alongside allene-oxide-synthase in the chloroplast.

In another research, GhAOC1 overexpression in Arabidopsis plants under copper stress increased their photosynthetic efficiency, survival rate, and fresh and dry weight of the stem (compared to control) and reduced the damage to the cell membrane and lipid peroxidation. The Real-time PCR analysis showed that in linseed, GhAOC transcripts are widely expressed in roots and regulated under $\mathrm{MeJAand} \mathrm{CuCl}_{2}$ stress (Wang et al., 2015). Research's has shown that MeJA synthesis is triggered through positive feedback, as genes that encode jasmonate synthesis are JA-inducible and jasmonate increases their expression.

\section{Conclusions}

In summary, this study identified and characterized AOC genes from wheat in $\mathrm{Cd}$ and MeJA treatment. AOC were expressed and significantly upregulated by $\mathrm{MeJA}$ and $\mathrm{CuCl}_{2}$ treatments.

It seems multiple pathways are involved in tolerance to $\mathrm{Cd}$ accumulation. It concluded that after MeJA treatment in plant under Cd stress, AOC gene as a key enzyme in the biosynthesis of MeJA increase. Overexpression of AOC led to increased expression of JA signaling genes and significantly higher fresh and dry weight, $\mathrm{Cd}$ accumulation, TF and BCF under $\mathrm{Cd}$ stress. AOC may prove to be a useful gene for molecular breeding of important crops to improve $\mathrm{Cd}$ stress tolerance. In conclusion, it appears that given the wide range of MeJA activities, this enzyme can be effective in controlling specific growth processes and enhancing plant stress tolerance. Therefor with 
overexpression of this enzyme can improve tolerance to heavy metals. Because of this, selected plant species with high accumulation potential could be used for revitalization of polluted areas.

\section{Bibliographic References}

Alayat, A., Souiki, L., Grara, N., Djebar, M.R., Boumedris, Z.E., Benosmane, S., Amamra, R., Berrebbah, H., 2014. Effects of cadmium on water content, soluble protein, proline changes and some antioxidant enzymes in wheat (Triticum durum desf.) leaves. Annual Research \& review in biology, 4(24), 3835-3847.

Azevedo, R.A., Garatao, P.L., Monteiro, C.C., Carvalho, R.F., 2012. What is new in the research on Cadmium-induced stress in plants? Food and Energy Security, 1(2), 133-140.

Bavi, K., Kholdebarin, B., Moradshahi, A., 2011. Effect of cadmium on growth, protein content and peroxidase activity in pea plants. Pak. J. Bot, 43(3), 1467-1470.

Benavides, M.P., Gallego, S.M., Tomaro, M.L., 2005. Cadmium toxicity in plants. Braz J Plant Physiol, 17(1), 2134.

Browse, J., 2009. Jasmonate passes muster: a receptor and targets for the defense hormone. Annuls Review of Plant Biology, 60, 183-205.

Chen, J., Yan, Z., Li, X., 2014. Effect of methyl jasmonate on Cadmium uptake and antioxidative capacity in Kandelia obovata seedlings under Cadmium stress. Ecotoxicology and Environmental Safety, 104, 349-356.

Creelman, R.A., Mullet, J.E., 1997. Biosynthesis and action of jasmonates in plants. Annuls Review of Plant Physiology and Plant Molecular Biology, 48, 355-381.

Da-lin, L., Kai-qi, H., Wei-Wei, Q., Xiu-ping, W., Shu-pan, Z., 2011. Effects of cadmium on the growth and physiological characteristics of sorghum plants. African journal of biotechnology, 10(7), 15770-15776.

Dar, T.A., Uddin, M., Khan, M.M.A., Hakeem, K.R., Hassan, J., 2015. Jasmonates counter plant stress. Environmental and experimental Botany, 115, 49-57.

De Maria, S., Puschenreiter, M., Rivelli, A.R., 2013. Cadmium accumulation and physiological response of sunf lower plants to $\mathrm{Cd}$ during the vegetative growing cycle. Plant Soil Environ, 59(6), 254-261.

Dias, M.C., Monterio, C., Moutinho-Pereira, J., Correia, C., Goncalves, B., Santos, C., 2013. Cadmium toxicity affects photosynthesis and plant growth at different levels. Acta Physiol Plant, 35, 1281-1289.

Gubrelay, U., Aghnihotri, R.K., Singh, G., Kaur, R., Sharma, R., 2013. Effect of heavy metal Cd on some physiological and biochemical parameters of Barley (Hordeum vulgare L.). International Journal of Agriculture and Crop Sciences, 5(22), 2743-2751.
Hasan, S.A., Fariduddin, Q., Ali, B., Hayat, S., Ahmad, A., 2009. Cadmium: Toxicity and tolerance in plants. J Environ Biol, 30(2), 165-174.

Kupper, H., Andresen, E., 2016. Mechanism of metal toxicity in plants. The Royal Society of Chemistry Metallomics, 8, 269-285.

Liu, W.X., Liu, J.W., Wu, M.Z., Li, Y., Zhao, Y., Li, S.R., 2009. Accumulation and translocation of toxic heavy metals in winter Wheat (Triticum aestivum L.) growing in agricultural soil of Zhengzhou, China. Bull Environ Contam Toxicol, 82, 343-347.

Livak, K.J., Schmittgen, T.D., 2001. Analysis of relative gene expression data using real-time quantitative PCR and the 2(Delta Delta C (T)) Method, 25, 402-408.

Maksymiec, W., Krupa, Z., 2006. The effects of short-term exposition to $\mathrm{Cd}$, excess $\mathrm{Cu}$ ions and jasmonate on oxidative stress spearing in Arabidopsis thaliana. Environmentsl and Experimentsl of Botany, 57,187-94.

Maksymiec, W., Wianowska, D., Dawidowicz, A.L., Radkiewicz, S., Mardarowicz, M., Krupa, Z., 2005. The level of jasmonic acid in Arabidopsis taliana and Phaseolus coccineus plants under heavy metal stress. Journal of Plant Physiology, 162, 1338-1346.

Mishra, S., Dubey, R.S., 2006. Heavy metal uptake and detoxification mechanism in plants. International Journal of Agricultural Research, 1(2), 122-141.

Nazar, R., Iqbal, N., Masood, A., Khan, M.I.R., Syeed, S., Khan, N.A., 2012. Cadmium toxicity in plants and role of mineral nutrients in its alleviation. American Journal of Plant Sciences, 3, 1476-1489.

Ouzounidou, G., Moustakas, M., Eleftheriou, E.P., 1997. Physiological and ultrastructural effects of Cadmium on Wheat (Triticum aestivum L.) leaves. Archive of Environment and Contam Toxicology, 32, 154-160.

Perez Chaca, M.V., Vigliocco, A., Reinoso, H., Molina, A., Abdala, G., Zirulnik, F., Pedranzani, H., 2014. Effects of Cadmium stress on growth, anatomy and hormone contents in Glycine max (L.) Merr. Acta Physiologia Plantarum, 36(10), 2815-2826.

Rezvani, M., Zaefarian, F., 2011. Bioaccumulation and translocation factors of Cadmium and lead in Aeluropus littoralis. AJAE, 2(4), 114-119.

Schaller, F., Zerbe, P., Reinbothe, S., Reinbothe, C., Hofmann, E., Pollmann, S., 2008. The allene oxide cyclase family of Arabidopsis thaliana - localization and cyclization. FEBS Journal, 275, 2428-2441.

Sheteawi, S.A., 2007. Improving growth and yield of saltstressed Soybean by exogenous application of jasmonic acid and ascobin. International journal of agriculture \& biology, 3, 473-478.

Singh, I., Shah, K., 2014. Exogenous application of methyl jasmonate lowers the effect of Cadmium-induced oxidative injury in rice seedlings. Phytochemistry, 108, 57-66. 
Stenzel, I., Hause, B., Miersch, O., Kurz, T., Maucher, H., Weichert, H., Ziegler, J., Feussner, I., Wasternack, C., 2003. Jasmonate biosynthesis and the allene oxide cyclase family of Arabidopsis thaliana. Plant Molecular Biology, 51, 895-911.

Stenzel, I., Otto, M., Delker, C., Kirmse, N., Schmidt, D., Miersch, O., Hause, B., Wasternack, C., 2012. Allene oxide cyclase (AOC) gene family members of Arabidopsis thaliana: tissue- and organ-specific promoter activities and in vivo heteromerization. Journal of Experimental Botany, 63(17), 6125-6138.

Thian, X., Li, Y., 2006. Nitric oxide treatment alleviates drought stress in wheat seedlings. Biology of Plant, 50(4), 775-778.

Wang, S., Wu, W., Liu, F., Liao, R., Hu, Y., 2017. Accumulation of heavy metals in soil-crop systems: a review for wheat and corn. Environment and Science Pollution Research, 24(18), 15209-15225.

Wang, Y., Liu, H., Xin, Q., 2015. Improvement of copper tolerance of Arabidopsis by transgenic expression of an allene oxide cyclase gene, GhAOCl, in upland cotton (Gossypium hirsutum L.). The Crop Journal, 3, 343-352.

Wang, Z.W., Nan, Z.R., Wang, S.L., Zhao, Z.J., 2010. Accumulation and distribution of $\mathrm{Cd}$ and lead in wheat (Triticum aestivum L.) grown in contaminated soils from the oasis, north-west China. Society of Chemical Industry, 91, 377-384.
Wasternack, C., Hause, B., 2013. Jasmonates: biosynthesis, perception, signal transduction and action in plant stress response, growth and development. Annals of Botany, 111(6), 1021-58.

Wu, Q., Wu, J., Sun, H., Zhang, D., Yu, D., 2011. Sequence and expression divergence of the AOC gene family in soybean: insights into functional diversity for stress responses. Biotechnol. Lett, 33, 1351-1359.

Yan, Z., Chen, J., Li, X., 2013. Methyl jasmonate as modulator of $\mathrm{Cd}$ toxicity in Capsicum frutescens var. fasciculatum seedlings. Ecotoxicology and Environmental Safty, 98, 203-209.

Yan, Z., Zhang, W., Chen, J., Li, X., 2015. Methyl jasmonate alleviates cadmium toxicity in Solanum nigrum by regulating metal uptake and anti-oxidative capacity. Biological Plantarum, 23, 42-51.

Yoon, J.Y., Hamayun, M., Lee, S.K., Lee, I.J., 2009. Methyle jasmonate alleviated salinity stress in Soybean. Journal of Crop Science and Biotechnology, 2, 63-68.

Zhao, Y., Dong, W., Zhang, N., Ai, X., Wang, M., Huang, Z., Xiao, L., Xia, G., 2014. A Wheat Allene Oxide Cyclase Gene Enhances Salinity Tolerance via Jasmonate Signaling. Plant Physiology, 164, 1068-1076. 